\title{
A Study of Energy Efficiency in Flats Case Study: The A-B-C Tower of Tambora Flats in Jakarta, Indonesia
}

\author{
Eugenius Rivado Victor Laude, Satriya Wahyu Firmandhani \\ Department of Architecture, Faculty of Engineering, Universitas Diponegoro, Indonesia \\ Corresponding e-mail: rivado@students.undip.ac.id
}

Article info:

Received: 27-04-2021, Revised: 30-04-2021, Accepted: 30-04-2021

\begin{abstract}
Flats are one of the government's solution to provide decent housing for low-income people. However, as mostly flats overlook energy efficiency aspects, residents must pay high rental and operational costs. Therefore, this paper aims to study the principles of green buildings, especially in the building envelope that can bear the operating costs of flats with the case study on the A-B-C Tower of Tambora Flats. The A-B-C Tower of Tambora Flats is one of the flats building in Jakarta that has rental cost issues. This study employed the EDGE application that provided energy saving values in the application of green building principles, such as building mass and orientation, wall and roof finishing materials, natural shading and ventilation elements. From these values, it was only the application of green building principles that was significant for the Tambora flats. The results of this study revealed that the optimization of natural ventilation for flats was still important and having a significant impact on energy savings
\end{abstract}

Keywords: Energy Efficiency, EDGE, Flats

\section{Introduction}

Flats as decent housings for low-income people tend to have various problems. Architectural problems that often occur in flats include poorly maintained public facilities and a decrease in the physical quality of the residential unit itself. The problems occur due to the lack of concern of residents and the maintenance costs (Katarina et al., 2011). One of the maintenance costs for the flats is the electricity bill. For example, one resident of the Rawa Bebek flats complained about the high cost of electricity even though it was only used for fans and lights until 6 pm (Hariyanto, 2017).

It is possible to reduce high maintenance or operational costs by applying energy saving principles in green buildings. An example in a building envelope is to pay attention to the shading elements and the ratio of the size of the opening to the massive field (Firmandhani \& Pandelaki, 2020). In addition to the purpose of operational cost reduction, green architectural principles are also driven by the phenomena of global warming and climate change. Climate change creates various disasters, which have significant impacts on the economy (Bauer et al., 2010). Ordinary people, businessmen and politicians turn their eyes to green building architecture. Green buildings are believed to be able to provide maximum comfort by paying attention to occupants' health aspects by depending on renewable energy sources that support the lowest possible operational costs (Bauer et al., 2010).

The Tambora Apartment, in the Tower A-B-C block as the object of this study is one of the flats in Jakarta intended for low-income people. These flats certainly have various problems (Aziza, 2016), both from high rental fees, electricity and water costs. Therefore, with the EDGE application as a tool to find the value of savings obtained from the application of green 
building principles, hopefully this study will be able to become a pilot for flats, especially for low-income people and revitalization of flats.

Previous research examined the importance of passive building envelope design elements on energy efficiency, including orientation, size of opening, and sun shading devices (Firmandhani and Pandelaki, 2020). This study examined the passive design with the addition of wall and roof finishing materials as well as the ability of the openings to allow natural ventilation with the latest EDGE version. Therefore, the purpose of the study is to examine the application of energy-efficient building principles in the A-B-C Tower building of the Tambora Jakarta Apartment (in the context of mass and building orientation, massive field materials and roofs, types of sun shading and natural ventilation) and find energy efficiency values based on the application of building principles. Tambora Flats with EDGE application simulation can be fulfilled. Hopefully this study can be an input for architects to design flats with affordable operational costs with decent housing for occupants in the future.

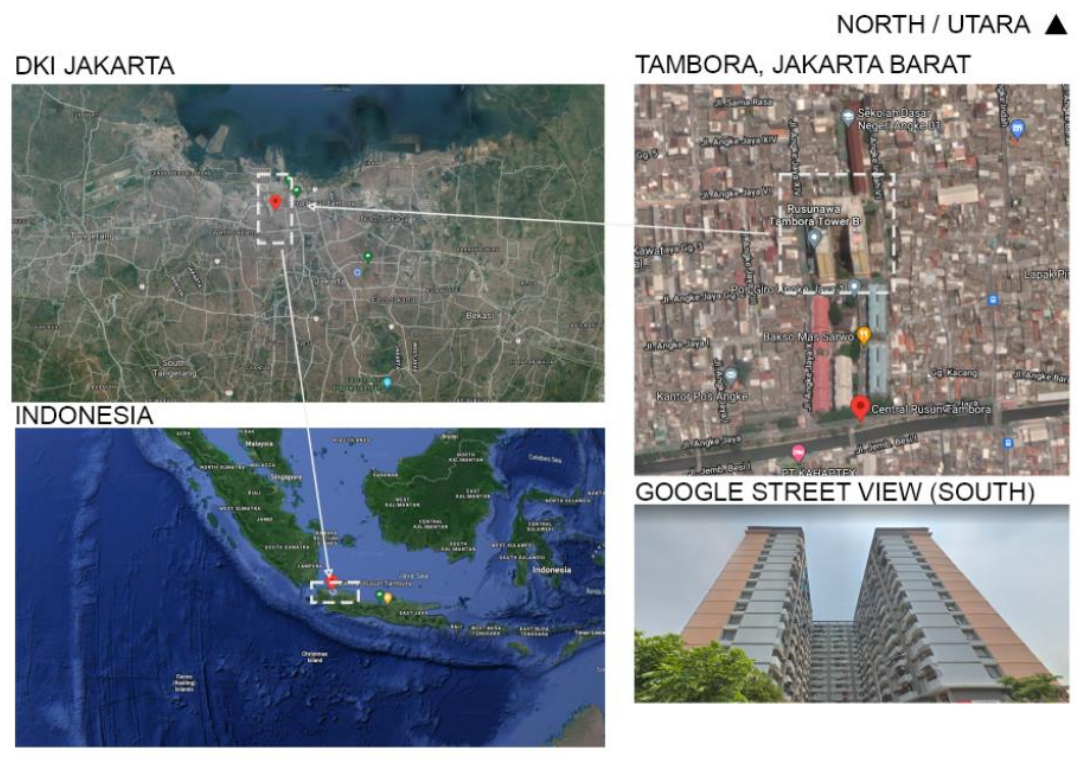

Figure 1.1. The Location of Study Area in Jakarta, Indonesia (Google, n.d.)

\section{Methods}

The study used a descriptive quantitative method. The prediction tool was Excellence Design for Greater Efficiency (EDGE) application established by International Finance Corporation (IFC), freely accessible online on app.edgebuildings.com. EDGE simulated the amount of energy saving values generated by the application of green building principles in one of the flats in Jakarta, the Tambora Flat. The study was carried out by the following processes:

(1) Data was collected in the field in the form of physical data for 1 block in the Tambora Flats of the A-B-C Tower. The data collected was in the form of applications of green building principles with quantities such as dimensions of massive walls, dimensions of openings, types, types of roofing materials of flat buildings, types of sun shading used and their dimensions, types of natural ventilation and dimensions.

(2) Field data was collected, entered into the EDGE application and calculated. The data was analysed based on the EDGE measure type of energy saving.

(3) The value of energy saving was found and the level of efficiency of the apartment building was concluded. 
This study was carried out in a pandemic period with health protocols that restricted access to flats and Universitas Diponegoro directions that discouraged learning outside the home. Therefore, some of the data in the form of measurements were the results of estimation based on photographs of research objects whose authenticity is guaranteed. To calculate the estimated size of the building, firstly researchers looked for the photos between the structural elements of the building, such as columns, with reference objects such as humans. The human size was assumed to be the average height of Indonesian, namely $158 \mathrm{~cm}$ (World Population Review, n.d.) with a standard length between the ends of the shoulders according to $50 \mathrm{~cm}$ and a side body width of $30 \mathrm{~cm}$ (Neufert \& Neufert, 2012). The photos were entered in an image processing application, such as Adobe Photoshop, then the manipulation of the cutting of the photos' area was carried out to focus on the column measurement and perspective manipulation to align the lines and objects in the photos so that they can be measured more accurately. Finally, the measurement was carried out by comparing the column object and human.

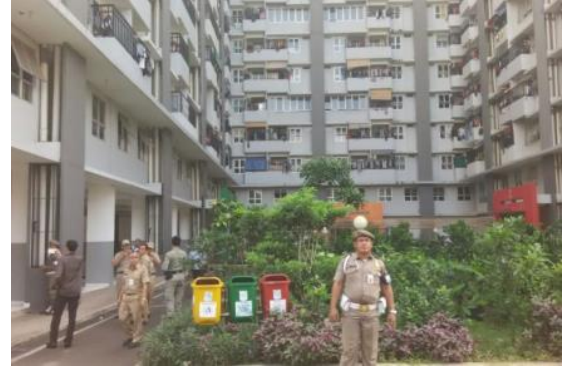

Figure 2.1. An example photo for estimation process (Rizky Adytia, 2016)

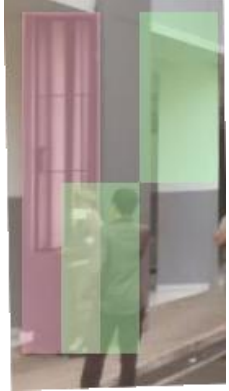

Figure 2.2. An estimation process using Adobe Photoshop.(Author Analysis, 2021)

Note: the red box is the column where the estimated height per floor that will be searched and the green box is the human element (one of the men in uniform) in the photo that will be used as a reference. It appears that column size is twice the human size (assuming $1.58 \mathrm{~m}$ ) so that the estimated column height per floor is 3.16 or $3.2 \mathrm{~m}$. This measure is used to measure the height of a building based on the number of floors

This research used the online EDGE application at the link https://app.edgebuildings.com/. The EDGE application used version 2.1.5 and version 3.0.0. The study was conducted with both versions aimed at version 2.1 .5 being released in 2019 and version 2021 . The different of this two versions is the 2019 version does not provide calculation of building dimensions and orientation, especially for the typology of homes (houses and flats) and hospitality (hotels, resorts), while the 2021 version has already calculated the dimensions and orientation of the building but is still in the trial / beta stage. From the two versions of the EDGE, similar steps were taken, the two values of savings were collected and a conclusion was drawn up based on these two values.

\section{Discussion}

The collected data were processed in the EDGE application. Sub Title 3.1 contains general data related to buildings, then Sub Titles 3.2 to 3.6 describe passive design elements and measures in the associated EDGE, where the specific HME XX code for EDGE version 2.1.5 and EEM XX code specifically for EDGE version 3.0.0. The calculation and simulation results are described in sub title 3.7 and 3.8. 


\subsection{Building Profile}

- Location : Tambora Cluster Flats, Angke, Tambora, West Jakarta, Jakarta Postal Code: 11330

- Area : $\pm 2500 \mathrm{~m} 2$

- Floor area : $\pm 1123 \mathrm{~m} 2$

- Number of storey: 16 floors

- Type : Revitalization flats

- Inaugurated :2015

- Capacity : 549 unit Type 30

- Facility : Elevator, shops, playground, library

\subsection{Building Mass and Orientation (HME 01: Reduced Window to Wall Ratio / or EEM 01: Window to Wall Ratio)}

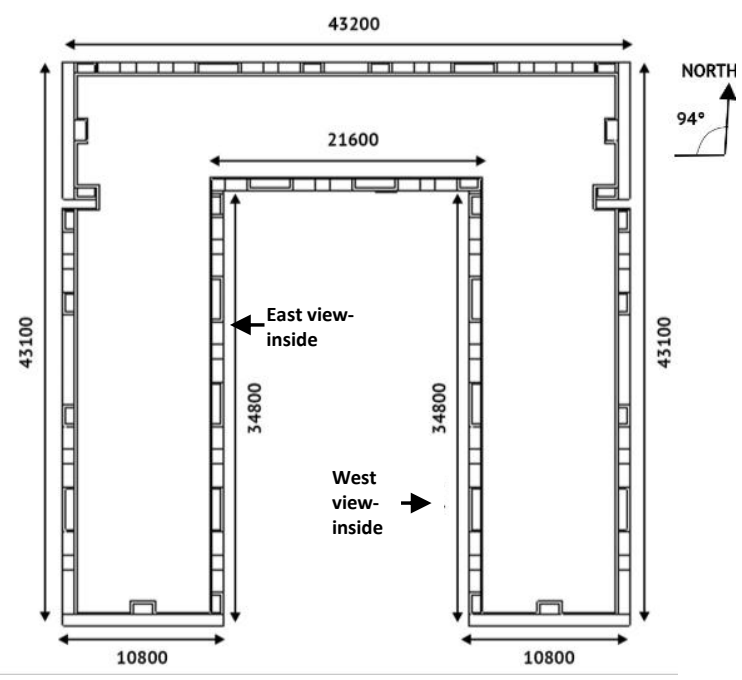

Figure 3.1. The Typical Layout Tower A-B-C (Author Analysis, 2021)

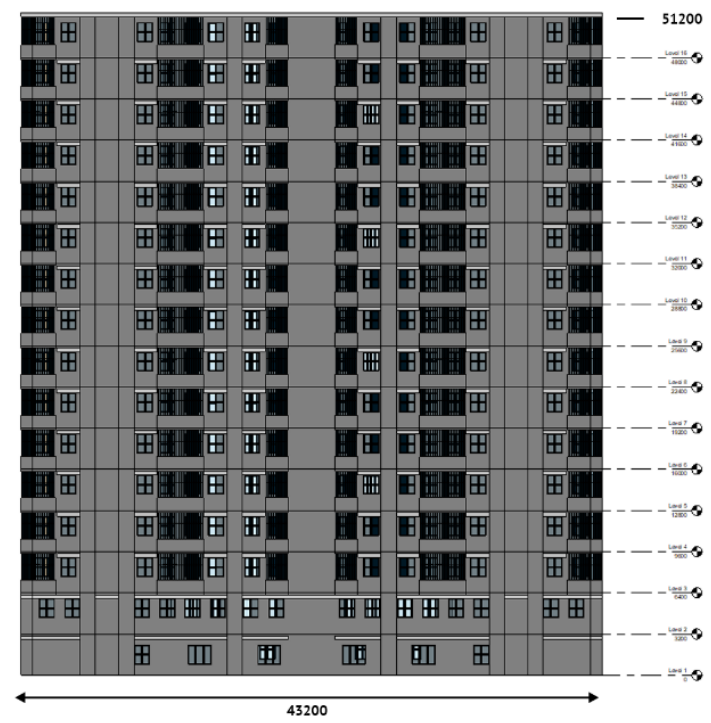

Figure 3.3. The North View of Tambora Tower A-B-C (Author Analysis, 2021)

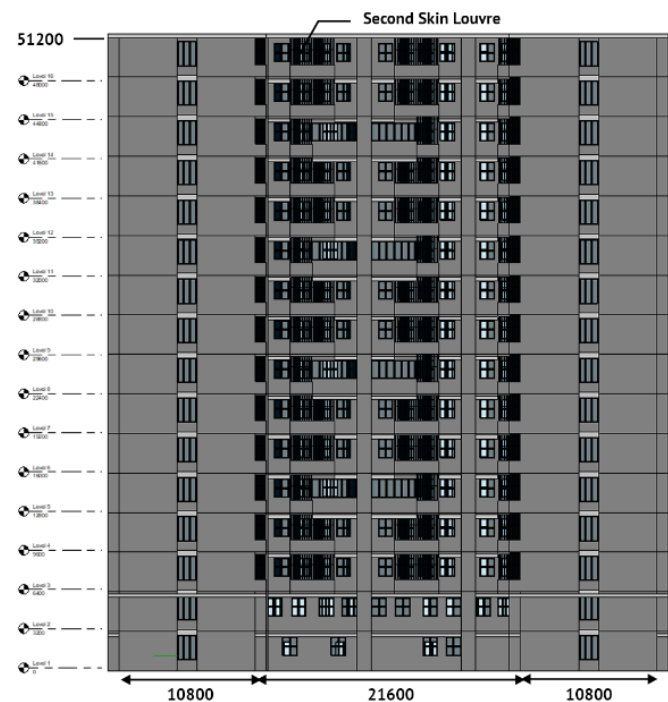

Figure 3.2. The South View of Tambora Tower AB-C (Author Analysis, 2021)

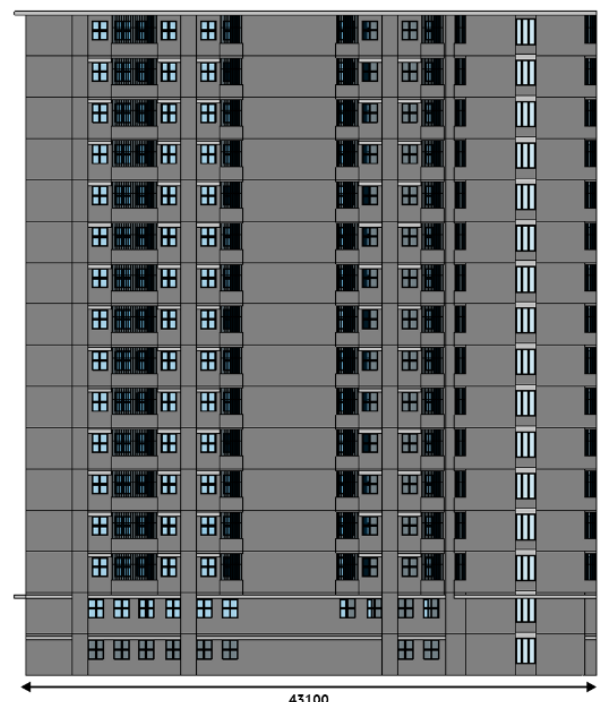

Figure 3.4. The East View of Tambora Tower A-B-C (Author Analysis, 2021) 


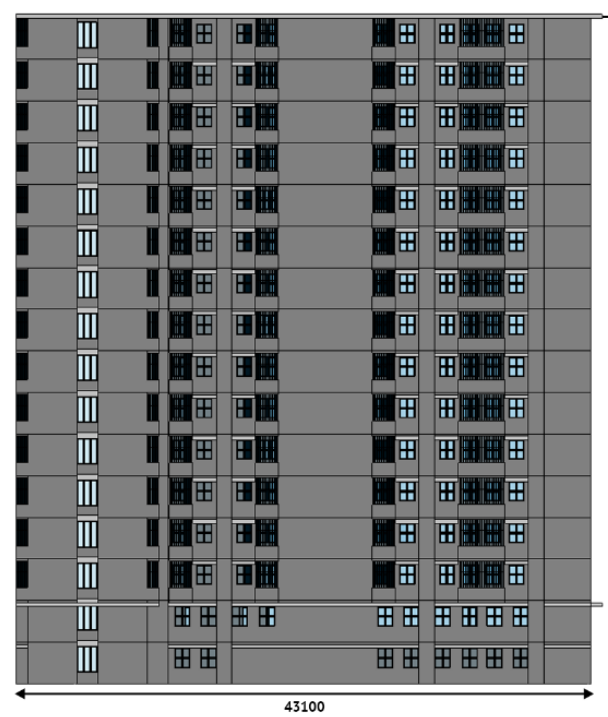

Figure 3.5. The West View of Tambora Tower A-B-C (Author Analysis, 2021)

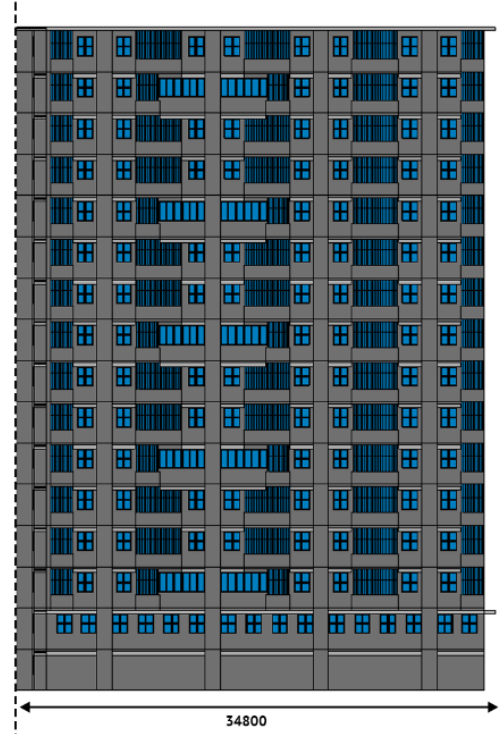

Figure 3.7. The West View-inside of Tambora Tower A-B-C (Author Analysis, 2021)

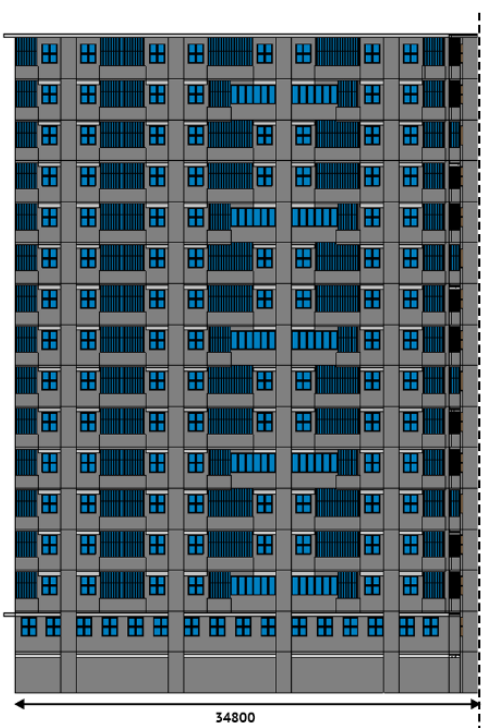

Figure 3.6. The East View-inside of Tambora Tower A-B-C (Author Analysis, 2021)

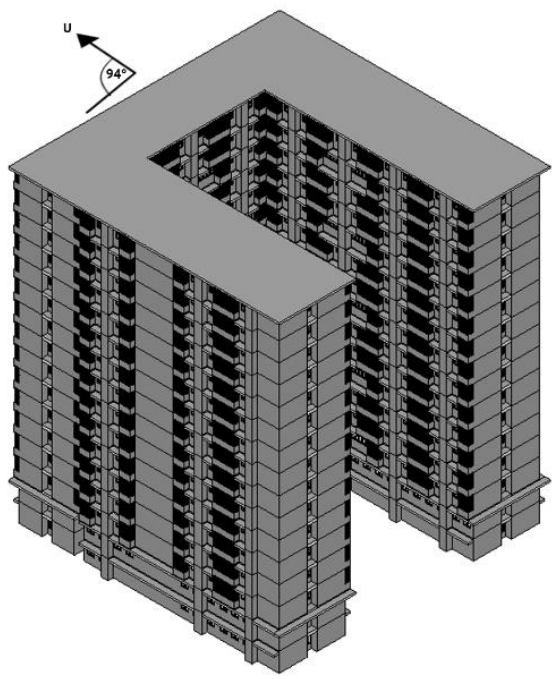

Figure 3.8. The Northwest Isometric of Tambora Tower A-B-C (Author Analysis, 2021)

Table 3.1. The Comparison of Massive Areas and the Total Openings on Each Side of The Building (Author Analysis, 2021)

\begin{tabular}{|c|c|c|c|c|}
\hline $\begin{array}{l}\text { ide of The } \\
\text { Building }\end{array}$ & $\begin{array}{l}\text { Massive } \\
\text { Area (m2) }\end{array}$ & \multicolumn{2}{|l|}{ Opening Area (m2) } & $\begin{array}{l}\text { WWR } \\
\text { Window to }\end{array}$ \\
\hline South & 2211.84 & $\begin{array}{l}\text { a) } 1.5 \mathrm{~m} \times 1.2 \mathrm{m:}: 76^{*} 1.8=136.8 \\
\text { b) } 0.6 \mathrm{~m} \times 1.5 \mathrm{~m}: 144^{\star} 0.9=129.6\end{array}$ & $=266.4$ & $12,04 \%$ \\
\hline North & 2211.84 & $\begin{array}{l}\text { a) } 1.5 \mathrm{~m} \times 1.2 \mathrm{~m}: 130^{*} 1.8=234 \\
\text { b) } 0.6 \mathrm{~m} \times 1.5 \mathrm{~m}: 12^{*} 0.9=10.8\end{array}$ & $=244.8$ & $11,07 \%$ \\
\hline East & 3988.48 & $\begin{array}{l}\text { a) } 1.5 \mathrm{~m} \times 1.2 \mathrm{~m}: 206^{*} 1.8=370.8 \\
\text { b) } 0.6 \mathrm{~m} \times 1.5 \mathrm{~m}: 108^{\star} 0.9=97.2\end{array}$ & $=468$ & $11,73 \%$ \\
\hline West & 3988.48 & $\begin{array}{l}\text { a) } 1.5 \mathrm{~m} \times 1.2 \mathrm{m:}: 206^{\star} 1.8=370.8 \\
\text { b) } 0.6 \mathrm{~m} \times 1.5 \mathrm{~m}: 108^{\star} 0.9=97.2\end{array}$ & $=468$ & $11,73 \%$ \\
\hline
\end{tabular}


HME 01 or EEM 01 is an effort to save energy in residential buildings by reducing the area of the opening to massive walls as a whole (International Finance Corporation, 2019, 2021). To find out the value of the savings, it is necessary to find the value of the window to wall ratio (WWR) for all sides of the building (north, east, west, south). WWR was obtained from the total area of massive walls and the total area of openings. After the WWR for each side was found, the measurement of HME 01 was checked in the EDGE application and the WWR values from all four sides were entered into the calculator menu in the EDGE application. This measure contributed to energy savings of $1.21 \%$ in version 2.1 .5 and $4.05 \%$ in version 3.0.0.

\subsection{Roof Material (HME 02: Reflective Paint / Tiles for Roof or EEM 02: Reflective Roof)}

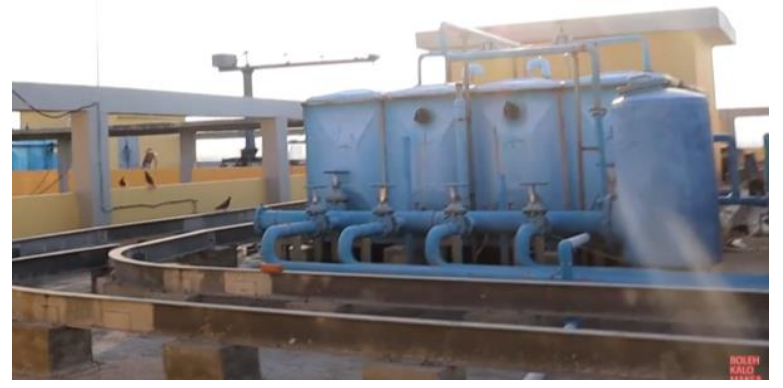

Figure 3.9. The roof finish is only gray concrete

HME 02 or EEM 02 is an effort to save energy in residential buildings by using a finishing material that reflects heat on the roof (International Finance Corporation, 2019, 2021). Based on data from the research results regarding roof finishing materials, it was necessary to find the Solar Reflectivity (SR) value based on the table provided by EDGE. Concrete skimmed material was considered not much different from the asphalt roof of the same colour. For asphalt roofing material, it had an SR value of $22 \%$ or 0.22 (International Finance Corporation, 2019). Measure HME 02 was checked and a value of 0.22 is entered into the SR column. This measure contributed to energy savings of $-0.05 \%$ in version 2.1 .5 and $4.06 \%$ in version 3.0 .0 .

\subsection{The Material Finishing Walls (HME 03: Reflective Paint for External Walls or EEM 03: Reflective Exterior Walls)}

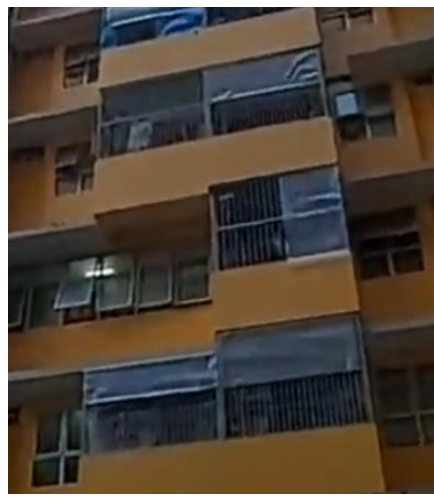

Figure 3.10. The Paint Finishing on Light Orange on entire wall (Imam Vina Official Youtube Account, 2020)

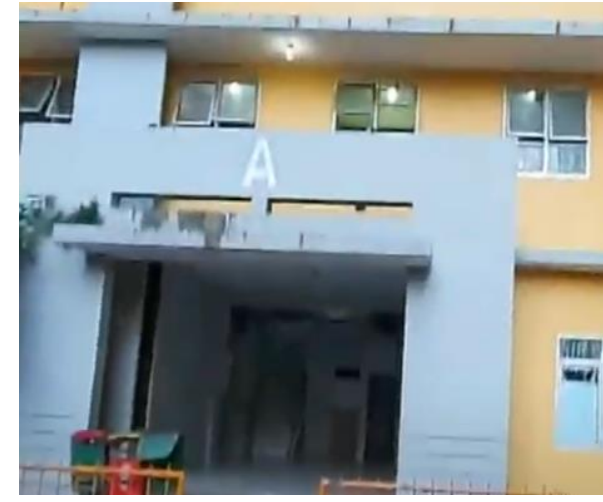

Figure 3.11. The Paint Finishing on Grey for the column and entrance wall (Imam Vina Official Youtube Account, 2020) 
HME 03 or EEM 03 is an effort to save energy in residential buildings by using a finishing material that reflects heat on the massive plane / wall (International Finance Corporation, 2019,2021 ). Based on data from research results regarding wall finishing materials, it was necessary to find the SR (Solar Reflectivity) value based on the table provided by EDGE. The paint material to be calculated was the light orange paint material because it was the finishing on the wall in direct contact with the occupants' activities. The light orange paint material based on the EDGE table included a medium coloured acrylic paint (half-light and half dark color paint) so that an SR value of $45 \%$ or 0.45 was obtained (International Finance Corporation, 2019). This measure contributed to energy savings of $0.07 \%$ in version 2.1.5 and $10.68 \%$ in version 3.0.0.

\subsection{Sun Shading Devices (HME 04: External Shading Devices or EEM 04: External Shading Devices)}

Table 3.2: The Comparison of Sun Shading Types and the Total Opening Area of Each Type (Author Analysis, 2021)

\begin{tabular}{|c|c|c|c|c|}
\hline Type & $\begin{array}{l}\text { Orientati } \\
\text { on }\end{array}$ & \multicolumn{2}{|c|}{ Opening Area (m2) } & Sun Shading Scheme \\
\hline \multirow[t]{4}{*}{$\begin{array}{l}\text { Horizontal } \\
\text { Overhang }\end{array}$} & North & $\begin{array}{l}\text { c) } 1.5 \mathrm{~m} \times 1.2 \mathrm{~m}: \\
130^{*} 1.8=234 \\
\text { d) } 0.6 \mathrm{~m} \times 1.5 \mathrm{~m}: \\
12^{*} 0.9=10.8 \\
\end{array}$ & $=244.8$ & \multirow{4}{*}{$D h=1 \mathrm{~m}$} \\
\hline & South & $\begin{array}{ll}\text { c) } & 1.5 \mathrm{~m} \times 1.2 \mathrm{~m}: \\
& 76^{*} 1.8=136.8 \\
\text { d) } & 0.6 \mathrm{~m} \times 1.5 \mathrm{~m}: \\
& 48^{*} 0.9=43.2\end{array}$ & $=180$ & \\
\hline & East & $\begin{array}{ll}\text { c) } & 1.5 \mathrm{~m} \times 1.2 \mathrm{~m}: \\
& 206^{\star} 1.8=370.8 \\
\text { d) } & 0.6 \mathrm{~m} \times 1.5 \mathrm{~m}: \\
& 60^{\star} 0.9=54\end{array}$ & $=424.8$ & \\
\hline & West & $\begin{array}{ll}\text { a) } & 1.5 \mathrm{~m} \times 1.2 \mathrm{~m}: \\
& 206^{\star} 1.8=370.8 \\
\text { b) } & 0.6 \mathrm{~m} \times 1.5 \mathrm{~m}: \\
& 60^{\star} 0.9=54\end{array}$ & $=424.8$ & \\
\hline \multirow{4}{*}{ Combination } & North & - & - & \\
\hline & South & 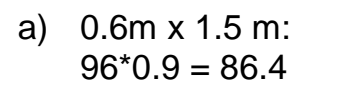 & $=86.4$ & \\
\hline & East & 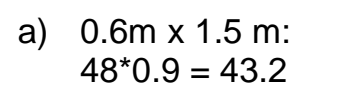 & $=43.2$ & \\
\hline & West & 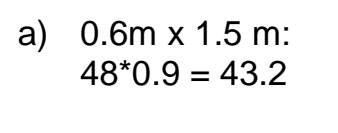 & $=43.2$ & $=1.5 \mathrm{~m}$ \\
\hline
\end{tabular}

HME 04 or EEM 04 is an effort to save energy in residential buildings by designing the construction of sun shading devices to reduce solar heat entering through openings (International Finance Corporation, 2019, 2021). In the EDGE calculation menu, the position of Latitude (latitude) and Hemisphere (hemisphere) was first set to 0-9 degrees and South (the position of Jakarta in the Southern hemisphere with a latitude of 6 degrees). Then each type of sun shading devices was entered for each side of the building/window orientation. 
Each type included the size of the opening area, and the ratio of the dimensions of the sun shading devices to the opening. After that, the Annual Average Shading Factor (AASF) value of each type of orientation and the average AASF value for all sun shading devices were found. They determined the energy saving value. This measure alone contributed to energy savings of $1.14 \%$ and $1.64 \%$ in version 3.0 .0 .

\subsection{Natural Ventilation (HME 09: Natural Ventilation or EEM 11: Natural Ventilation)}

The flats have openings on all sides, allowing air circulation crosses from the west side to the east side, the south side to the north side and vice versa. This is also supported by the flats units which also have windows that can be opened to the corridor in the middle of the building mass.

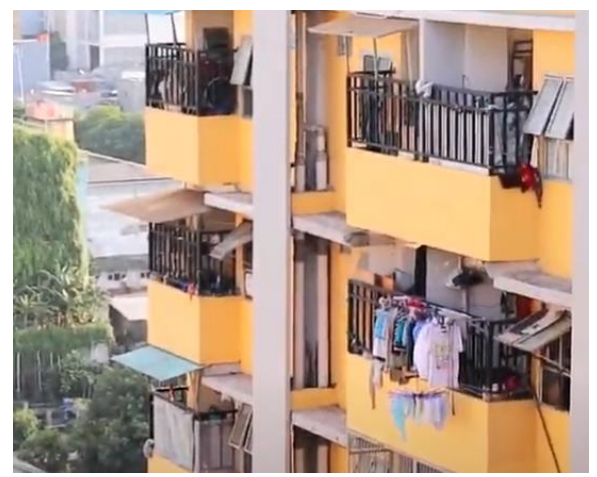

Figure 3.12. The Opening Windows

(Rumsun Boys Youtube Account, 2019)

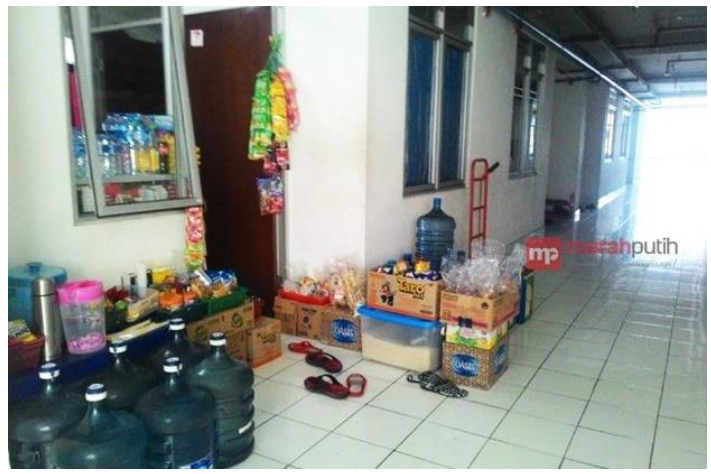

Figure 3.13. The Opening on the Flat Unit to Corridor. (Amalia, 2016)

HME 09 or EEM 11 is an effort to save energy in residential buildings by regulating openings that allow air circulation, which can create natural ventilation (International Finance Corporation, 2019, 2021). Because the data needed is for each apartment unit, the calculation was carried out according to the EDGE assumption, namely natural ventilation that is able to reduce the temperature when the outside temperature is still cool (International Finance Corporation, 2019). Because based on the data, the apartment building has openings that allow cross air circulation, then the measure HME 09 was simply checked. This measure contributed to energy savings of $3.42 \%$ and $53.84 \%$ in version $\mathbf{3 . 0 . 0}$.

\subsection{The Calculation Result and Simulation EDGE 2.1.5 Version}

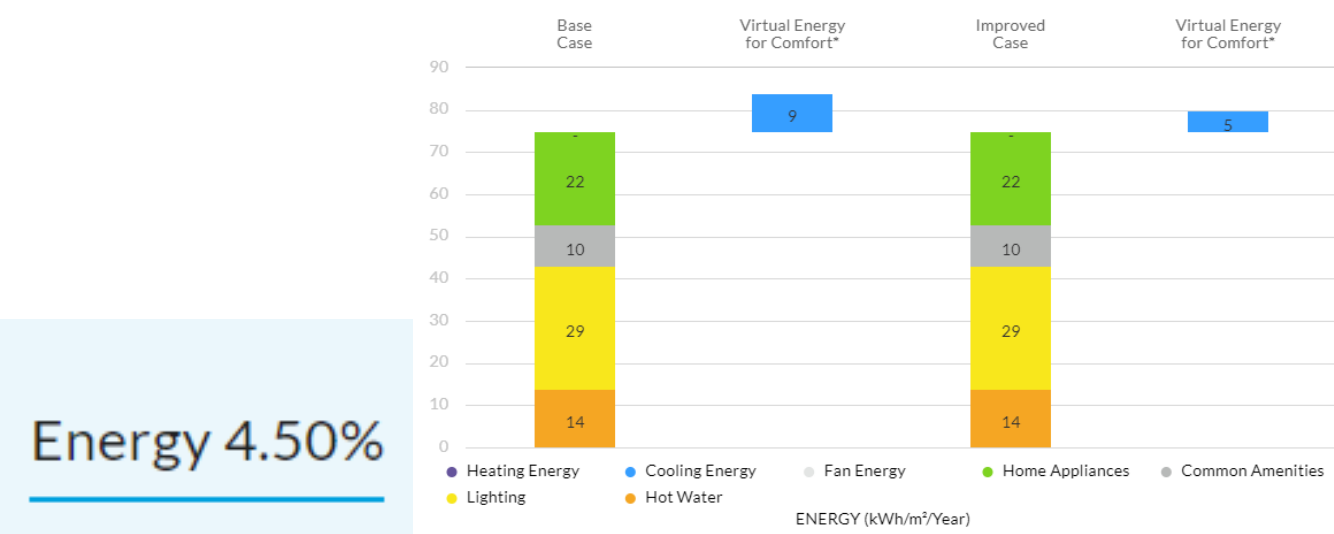

Figure 3.14. The comparison diagram of energy consumption before and after the application of the principles of green building based on EDGE version 2.1.5 (Author Analysis, 2021) 
Flats buildings have no significant energy savings based on EDGE standards. The energy efficiency value obtained from the building envelope was a ratio of massive wall construction to openings, using of reflective materials for walls and roofs, as well as using sun shading devices with natural ventilation efforts of only $4.5 \%$, far from the EDGE standard of $20 \%$.

\subsection{The Calculation Result and Simulation EDGE 3.0.0 Version}

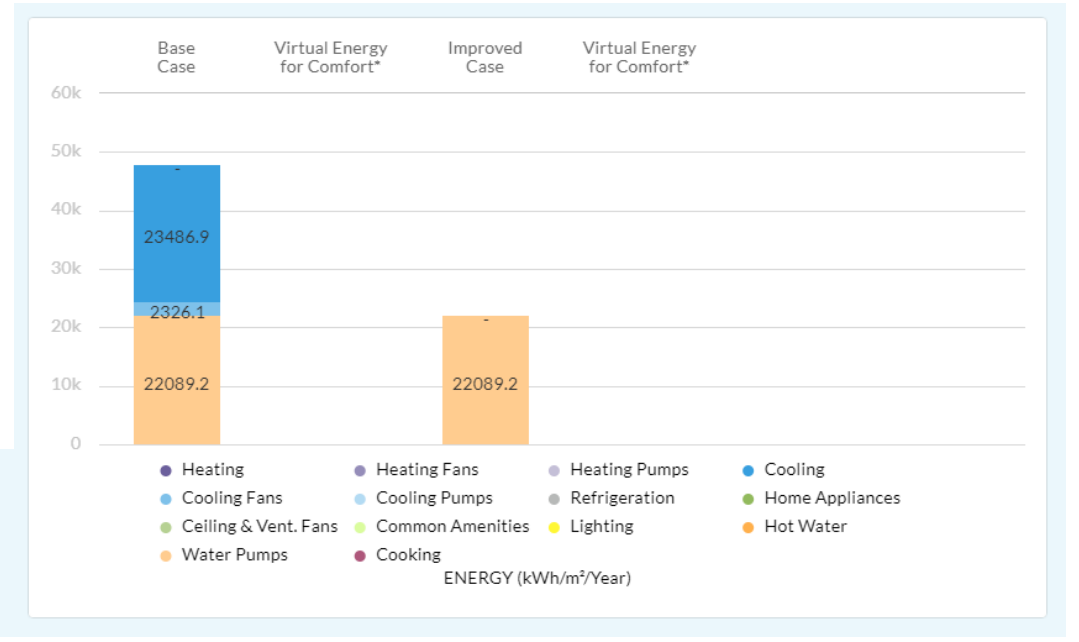

Figure 3.15. The comparison diagram of energy consumption before and after the principles of green building based on EDGE version 3.0.0 (Author Analysis, 2021)

The flats for this version had substantial energy saving that exceed EDGE standards. The energy efficiency value obtained from the building envelope was a ratio of massive wall construction with openings, using of reflective materials for walls and roofs and using sun shading devices, with natural ventilation efforts of $53.84 \%$, far from the value in the previous version of $4.5 \%$.

\section{Conclusion}

In terms of the building envelope, the A-B-C Tower in the Tambora Flats Jakarta had no significant savings (4.58\%) based on the EDGE standard in version 2.1.5 and but had a large savings value (53.84\%) in version 3.0.0. The factors that caused the low level of energy saving of the five measures in version 2.1.5, from the most to the least influential factors were the roof finishing material that was too dark, the wall finishing material that was not bright enough, the sun shading devices that lacked the shade, the WWR ratio of the building and natural ventilation. Meanwhile, the factors that caused the high level of energy saving of the five measures in version 3.0.0, in order from most to least influential factors were natural ventilation, wall finishing materials, roof finishing materials, building WWR ratio, and sun shading devices. The measure that had the same result in both versions was natural ventilation. In both versions the natural ventilation itself had the highest savings value.

The three points of conclusion that can be drawn are, (1) An optimization of the thermal aspects of the building envelope does not have a significant impact on energy savings for flats with natural ventilation, (2) An optimization of natural ventilation for apartment buildings is still important and has a significant impact for energy savings, (3) The results of this study differed from the results of previous studies that the orientation of the buildings, more precisely the WWR elements and shading, which had major effects on energy efficiency. 


\section{Acknowledgments}

The author thanks to all of the parties that have supported this study, especially the International Finance Corporation (IFC) that has been providing EDGE application accessible freely. Therefore this study could be conducted by EDGE application.

\section{References}

Aziza, K. (2016). Bertemu Djarot, Penghuni Rusun Tambora Keluhkan Mahalnya Biaya Sewa. KOMPAS.Com.

Bauer, M., Mösle, P., \& Schwarz, M. (2010). Green Building. Springer Berlin Heidelberg. https://doi.org/10.1007/978-3-642-00635-7

Firmandhani, S. W., \& Pandelaki, E. E. (2020). ORIENTASI BANGUNAN RUMAH SUSUN MENUJU HUNIAN VERTIKAL YANG EFISIEN ENERGI Studi Kasus Blok A dan B, Rumah Susun Kudu Semarang. https://doi.org/10.14710/mdl.20.01.2020.37-43

Google. (n.d.). [Streetview and Maps of Rusunawa Tambora, Jakarta Barat, DKI Jakarta].

Hariyanto, I. (2017). Pindah ke Rusun, Warga Bukit Duri Keluhkan Biaya Listrik Mahal. Detiknews.

International Finance Corporation. (2019). EDGE User Guide for All Building Types Version2.1_d-1.

International Finance Corporation. (2021). EDGE User Guide for All Building Types Version 3.0.a Beta.

Katarina, W., Nurdiani, N., \& Mariana, Y. (2011). Permasalahan Rumah Susun Sederhana di Perkotaan. Evaluasi Pengembangan Rumah Susun Sederhana di DKI Jakarta. Evaluasi Pengembangan Rumah Susun Sederhana Di DKI Jakarta.

Neufert, E., \& Neufert, P. (2012). Architects' Data (4th ed.). John Wiley \& Sons.

World Population Review. (n.d.). Average height by country 2020. 